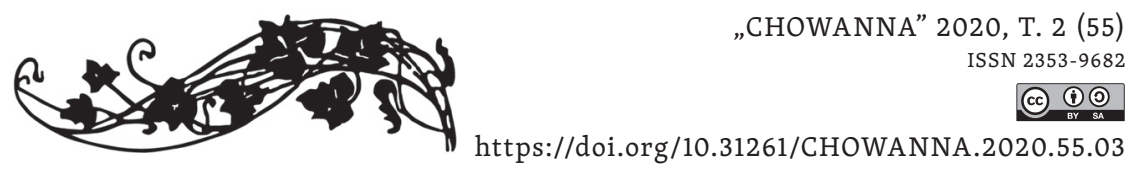

s. 1 z 14

\title{
Irena Przybylska
}

Uniwersytet Śląski w Katowicach

(iD) https://orcid.org/0000-0001-6688-8549

\section{Kryzys więzi międzyludzkich jako kryzys kultury emocjonalnej}

\section{A Crisis of Interpersonal Bonds as a Crisis of Emotional Culture}

\begin{abstract}
The article attempts to describe the symptoms of the crisis of interpersonal bonds in the perspective of the crisis of emotional culture. The core of the analyzes of the causes and symptoms of the crisis of interpersonal ties are the concepts related to the emotional turn and the discursive dimension of affective life. The crisis of emotional culture is described in the text in the light of progressive individualization and diminishing intimacy, which supersedes the commonality of goals and attitudes. The main thesis of the text is that the invasiveness of expert discourses and consumer culture leads to the wind-down of emotional culture, rationalization of the private sphere and breaking axio-normative constraints that regulate social attitudes, also in the dimension of creating and maintaining interpersonal bonds.
\end{abstract}

Keywords: relationships between people, intimacy, the wind-down of emotionality

\section{Refleksyjna praktyka w związkach intymnych - wprowadzenie}

Jakkolwiek zdefiniujemy relację między ludźmi (więź, bliskość, czysta relacja, intymnośćl), aby mogła ona trwać, niezbędne jest zaangażo-

${ }^{1}$ W tekście kategorie „bliskość” i „intymność” są stosowane zamiennie. Nie odnoszą się tylko do związków małżeńskich, partnerskich, ale szerzej - do relacji przyjacielskich i rodzinnych. 
wanie, które łączy się z rosnącym współcześnie ryzykiem odrzucenia i obawą przed końcem relacji ${ }^{2}$. „Odwołanie” zaangażowania jest coraz częściej możliwe, a nawet uprawomocnione. Skoro - jak pisze Bauman - ponowoczesny byt jest ciągłym poszukiwaniem, to każda relacja może ograniczać szanse na „spełnienie powołania - urzeczywistnienie potencjału" i kolejną próbę dokończenia konstrukcji tożsamości ${ }^{3}$. Filozof dodaje, iż „Nieobecność struktur społecznych, jakie wyznaczałyby raz na zawsze (to znaczy, praktycznie biorąc, na okres realizacji »projektu życiowego«) ramy tego, co możliwe, ale zarazem byłyby wsparciem dla wysiłków skierowanych na realizację którejkolwiek z obranych możliwości, jest bodaj najdobitniejszą cechą wyróżniającą byt ponowoczesny" ${ }^{4}$, byt, którego struktura i zmienne ramy działania potęgują „elastyczność” (konieczność bycia elastycznym) w pracy, wykształceniu, zachowaniu oraz w interesujących nas tu relacjach międzyludzkich (we wchodzeniu, w utrzymywaniu i rezygnowaniu z relacji).

Refleksyjność, dystynktywny składnik ludzkich postaw, współcześnie nabiera nowego znaczenia i dotyczy właściwie wszystkich działań człowieka i praktyk społecznych w społecznościach, w których tradycyjne reguły, wzory i mechanizmy stabilizacyjne przestają obowiązywać. Oczekuje się od ludzi stałego utrzymywania kontaktu z podstawami własnego działania nie tylko w pracy zawodowej, w sferze publicznej, lecz także w sferze relacji społecznych i w życiu prywatnym. Nawet kategorie, kiedyś trwałe, niezmienne, związane z miejscem i jego kulturą, jak tożsamość i rola społeczna, uznaje się za pochodne pragnień i własnego projektu życiowego, który nie jest realizowany według logiki przyczynowo-skutkowej, a rezonuje z niespójnością, niekonsekwencją postępowania, fragmentaryzacją i epizodycznością aktywności współczesnego człowieka. Te Baumanowskie „chroniczne atrybuty ponowoczesnego stylu życia” dotyczą także relacji społecznych ${ }^{5}$. Ich tymczasowość to przejaw (i wtórnie przyczyna) dramatycznych przemian w sferze intymnej - ochładzania i racjonalizowania emocjonalności, których źródło Eve Illouz dostrzega w systemie wymuszającym przenoszenie logiki projektowej na życie

${ }^{2}$ A. Giddens: Przemiany intymności: seksualność, miłość i erotyzm we wspótczesnych społeczeństwach. Przeł. A. Szulżycka. Warszawa 2006, s. 164.

3 Z. Bauman: Ponowoczesne wzory osobowe. „Studia Socjologiczne” 2001, nr 1 (200), s. 439.

${ }^{4}$ Ibidem, s. 440.

${ }^{5}$ Z. Bauman: Ponowoczesne wzory osobowe... 
osobiste i jednoczesne wykorzystanie emocji jako zasobu (kompetencji) pracownika 6 .

Skoro możesz być, kim zechcesz, to możesz być, z kim zechcesz, i decyzję o tym, z kim jesteś, zmieniać, kiedy tylko odczujesz brak satysfakcji z dotychczasowej relacji. Dowolność sprawia, że stoimy przed koniecznością „wyboru nieskończonej liczby możliwości tworzenia, poprawy, naprawy i rozwiązywania swoich związków z innymi"7. Relacje między partnerami, krewnymi, przyjaciółmi, kiedyś rodzące się spontanicznie, często bez konieczności uświadamiania sobie, że poszukuję kogoś lub jestem z kimś związany, obecnie wymagają przygotowania, specjalnych kompetencji, monitorowania rozwoju relacji i własnego z niej zadowolenia. W ostateczności gdy rezygnujemy ze związku lub planujemy jego rozwój, odwołujemy się do dyskursów eksperckich - zachodzi kolonizacja emocji i więzi międzyludzkich ${ }^{8}$.

\section{Czysta relacja - zmiana paradygmatu (od „my” do „ja”)}

Za punkt wyjścia analizy przemian w obrębie więzi międzyludzkich można przyjąć kategorię intymności. Jeśli za Ernstem Cassirerem przyjrzymy się intymności przez pryzmat tworzonej przez ludzi kultury, to możemy uznać, że diagnoza intymności jest wskaźnikiem stanu więzi międzyludzkich i szerzej: kondycji ludzkiej w posttradycyjnych społeczeństwach $^{10}$. Zdaniem Anthony’ego Giddensa późnonowoczesna intymność realizuje się w czystej relacji (pure relationship), która „staje się w coraz większej mierze związkiem tworzonym i podtrzymywanym o tyle, o ile bliski kontakt z drugą osobą jest źródłem satysfakcji emocjonalnej [...]. Inne jego [związku - I.P.] aspekty, nawet pozornie tak fundamentalne, jak posiadanie dzieci, nie tylko nie cementują związku, ale mogą przyczyniać się do jego postępującego rozkładu"11. Tak definiowana intymność nabiera znaczenia transakcji, w którą part-

${ }^{6}$ E. Illouz: Uczucia $w$ dobie kapitalizmu. Przeł. Z. Simbierowicz. Z oryginałem porównał J. Niżnik. Zredagowała, indeks osób i postaci wraz z notą biograficzną przygotowała E. Nowakowska-Sołtan. Warszawa 2010.

${ }^{7}$ A. Giddens: Socjologia. Współpr. Ph.W. Sutton. Tłum. O. Siara, A. Szulżycka, P. Tomanek. Warszawa 2012, s. 198.

${ }^{8}$ A. Giddens: Nowoczesność $i$ tożsamość. "Ja" i społeczeństwo w epoce późnej nowoczesności. Tłum. A. Szulżycka. Warszawa 2010, s. 128.

9 Zob. L. Jamieson: Intimacy: Personal Relationships in Modern Societies. Cambridge-Malden 1998.

10 E. Cassirer: Esej o człowieku. Wstęp do filozofii kultury. Przeł. A. Staniewska. Przedmową poprzedził B. Suchodolski. Wyd. 2. Warszawa 1977.

${ }^{11}$ A. Giddens: Nowoczesność i tożsamość..., s. 126. 
nerzy inwestują, dopóki zaspakaja ona ich potrzeby i daje satysfakcję. „Więzy i więzi - mówi Bauman - odbierają relacjom międzyludzkim »czystość« - tak jak odbierałyby ją każdemu aktowi konsumpcji, który zakłada natychmiastowe zaspokojenie i równie natychmiastowe zniknięcie przedmiotu konsumpcji"12, dlatego relacje stają się epizodyczne i temporalne: na pewien czas, na weekend, na wieczór... Coraz częściej więzi, które powinny wiązać (bonding capital) - mam na myśli więzi rodzinne - przybierają postać zdecydowanie słabszych więzi pomostowych (bridging capital) ${ }^{13}$. Więzi pomostowe wprawdzie umożliwiają dostęp do zasobów i informacji ulokowanych poza rodziną i przez to aktywizują inne relacje społeczne, rozluźnienie tych więzi w tak ważnym środowisku wychowawczym jak rodzina przyczynia się jednak do zaburzenia reprodukcji kulturowych wzorów intymności, bliskości i budowania więzi ${ }^{14}$.

W Giddensowskim rozumieniu „czystość” relacji oznacza jej względną niezależność od zewnętrznych uwarunkowań życia społecznego i ekonomicznego, a zależność tylko od „nowoczesnego zaufania”, opartego na autentyczności i wzajemności ${ }^{15}$. Tym samym pojęcie zaproponowane przez Giddensa wpisuje się, przynajmniej z perspektywy negocjowania zakresu zaangażowania i wolności, w dyskurs emancypacyjny. Autonomiczna sfera komunikacyjna czystej interakcji, w której zakres indywidualnej wolności i obszary współpracy (wspólnoty) są negocjowane, a nie uznane, jest zmaksymalizowana. Jako taka „nowoczesna” relacja może być przykładem rosnącej wolności negatywnej (uwolnienie od wszelkich norm obyczajowych), ale i pozytywnej, rozumianej jako emancypacja relacji intymnej oraz emancypacja partnerów, która jest uzyskiwaniem i poszerzaniem granic ich wolności oraz zakresów równości ${ }^{16}$. Czy jest jednak przykładem rozwoju relacji międzyludzkich, czy raczej ich niebezpiecznego - z perspektywy bezpieczeństwa egzystencjonalnego - dekonstruowania?

12 Z. Bauman: Razem, osobno. Przeł. T. Kunz. Kraków 2003, s. 140.

13 Nawiązuję do Roberta Putnama teorii kapitału społecznego pomostowego i wiążącego. Podaję za: M. Adamczyk: Wprowadzenie do teorii kapitału społecznego. Lublin 2013.

${ }_{14}$ Zgodnie z koncepcją Putnama wiążący i pomostowy kapitał społeczny nie wykluczają się. Dotyczy to także rodziny, która może mieć zasoby obydwu kapitałów. W pewnych aspektach kapitał rodziny może być wiążący (na przykład wspólnota wartości) i równocześnie w innych pomostowy (na przykład swoboda w podejmowaniu aktywności poza rodziną). Podaję za: M. Adamczyk: Wprowadzenie do teorii kapitału społecznego...

15 A. Giddens: Nowoczesność i tożsamość..., s. 125.

${ }^{16}$ A. Giddens: Przemiany intymności..., s. 27. 
W modelowej czystej relacji miłość w sensie romantycznym nie jest możliwa, zakłada bowiem nierówność płci wynikającą z odmiennych ról w relacji. Uczucie, które może łączyć partnerów, Giddens opisuje jako miłość współbieżną (confluent love), gdyż ta nie ogranicza emocjonalnie, a realizuje uniwersalną zasadę egalitarności i wolności partnerów w związku. Miłość współbieżna jest redukowana tylko do zaangażowania i obopólnej satysfakcji, dlatego - zdaniem Anthony'ego Giddensa, Arlie Russell Hochschild, a także Catherine A. Lutz - ludzie współcześnie nie szukają „kogoś szczególnego”, ale projektują „szczególną relację”, tylko na pewien czas ${ }^{17}$ : „związków międzyosobowych nie zawiera się na ogół z myślą, że trwać będą »aź śmierć nas rozdzieli«. Coraz częściej się zdarza, że zamierza się ich tymczasowość z góry i oblicza się je na tak długo tylko, jak trwać będzie zadowolenie z nich czerpane. Związki niezaopatrzone w klauzulę wymówienia, związki, jakich nie można zerwać, nawet gdy motywy ich zawiązania utraciły moc, wydają się równie sprzeczne z rozsądkiem, jak podpisanie czeku bez wpisania sumy, na jaką opiewa, odczuwane są jak gwałt zadany niezbywalnej autonomii podmiotu" ${ }^{18}$.

Intymność w relacji „czystej” od przywiązania, oddania, od myślenia w kategoriach „my” jest charakterystyczna dla związków w wysoko zindywidualizowanej kulturze, w której satysfakcja i osobista samorealizacja są warunkami trwania relacji. Partnerów nie łączą cele i wartości wspólnotowe, a znaczenia i reguły wspólnego życia są podporządkowane realizacji celów indywidualnych i dlatego muszą być nieustająco negocjowane ${ }^{19}$. Uczucia w takim związku również mają wartość transakcyjną - są racjonalizowanym przedmiotem pracy emocjonalnej (emotional work), która wpisuje się w interesujące nas tu zjawiska komercjalizowania emocji i ochładzania relacji ${ }^{20}$.

Gdyby przyjąć perspektywę Giddensa, trzeba by stwierdzić, że demokratyzacja sfery prywatnej już się dokonała i jest realną właściwością życia osobistego, która realizuje się w czystej relacji. Giddens w zmianie w sferze prywatnej widzi wzór emocjonalnej przebudowy życia społecznego oraz demokratyzacji stosunków w sferze publicz-

${ }_{17}$ Podaję za: M. Grochalska: Kobiety w związkach jako ofiary dyskursu „szczęśliwej rodziny". W: Zagadnienia małżństwa i rodzin w perspektywie feministyczno-genderowej. Red. K. Slany. Kraków 2013, s. 146.

18 Z. Bauman: Ponowoczesne wzory osobowe..., s. 442.

${ }_{19}$ M. Marody: Jednostka po nowoczesności: perspektywa socjologiczna. Wyd. 2, dodruk. Warszawa 2016.

${ }^{20}$ A.R. Hochschild: The Commercialization of Intimate Life: Notes from Home and Work. Berkeley-Los Angeles 2003, s. 208. 
nej ${ }^{21}$. Z perspektywy zaspokojenia potrzeb emocjonalnych człowieka nietrwałość więzi, mimo że łącząca się z możliwością projektowania związku, jest jednak niebezpieczna, gdyż przesuwa uwagę na czerpanie satysfakcji z relacji, które zamiast pojawiać się i trwać naturalnie podtrzymywane przez sympatię, przyjaźń czy miłość stają się przedmiotem samokontroli, zarządzania czasem, emocjami i samą relacją. Praca człowieka nad relacją i jednoczesne jego skupienie się na sobie angażuje go emocjonalnie i zaburza ciągłość doświadczeń rodziny, dezorganizuje świat życia i może prowadzić do osamotnienia, frustracji i lęków ${ }^{22}$. Giddens wprawdzie przyznaje, że niepewność może obniżać poczucie bezpieczeństwa ontologicznego i prowadzić do uzależnień, ale jako entuzjasta czystej relacji sposobów pokonania trudności upatruje w poradach eksperckich, których funkcją jest zasadniczo rozwiązywanie problemów życia intymnego, natomiast czystą relację traktuje jako bezdyskusyjną wartość w związku i dobro, o które należy dbać ${ }^{23}$.

Entuzjazm Giddensa dotyczący możliwości zmian w relacjach intymnych podzielają między innymi Jeffre Weeks i Brian McNair ${ }^{24}$. Bardziej ambiwalentnie do przemian intymności podchodzą Ulrich Beck i Elizabeth Beck-Gernsheim ${ }^{25}$, Zygmunt Bauman ${ }^{26}$, Arlie Russell Hochschild $^{27}$ oraz Eve Illouz ${ }^{28}$. Socjologowie dostrzegają możliwości, jakie w obrębie relacji intymnych stwarza indywidualizacja i emancypacja $\mathrm{z}$ ról oraz norm, ale także napięcia, jakie są generowane przez wzrost wolności i autonomii w tych relacjach ${ }^{29}$. W przemianach intymności upatrują źródła rozpadu więzi i chłodzenia emocjonalności, a ich przyczyny lokują w strukturze społecznej i kulturze. W kolejnych częściach tekstu odwołam się do stanowisk jeśli nie krytycznych, to przynajmniej problematyzujących związek pomiędzy indywidualizacją a tworzeniem i utrzymywaniem więzi.

Stanowisko Becka i Beck-Gernsheim wyróżnia się, poza krytyczną oceną ochładzania emocjonalności w bliskich związkach, nobilitacją

${ }^{21}$ A. Giddens: Przemiany intymności..., s. 217.

${ }^{22}$ A. Giza-Poleszczuk: Rodzina a system społeczny. Reprodukcja i kooperacja w perspektywie i nterdyscyplinarnej. Warszawa 2005.

${ }^{23}$ Ibidem, s. 216.

${ }^{24}$ J. Weeks: The World We Have Won: The Remaking of Erotic and Intimate Life Since 1945. London-New York 2007; B. McNair: Porno? Chic!: How Pornography Changed the World and Made It a Better Place. Abingdon-New York 2012.

${ }^{25}$ U. Beck, E. Beck-Gernsheim: The Normal Chaos of Love. Cambridge 1995.

${ }^{26}$ Z. Bauman: Razem, osobno...

${ }^{27}$ A.R. Hochschild: Zarządzanie emocjami. Komercjalizacja ludzkich uczuć. Tłum. J. Konieczny. Warszawa 2009.

${ }^{28}$ E. Illouz: Uczucia $w$ dobie kapitalizmu...

${ }^{29}$ Por. M. Marody: Jednostka po nowoczesności: perspektywa socjologiczna... 
miłości do statusu nowej religii (secular religion), w której partnerzy są dla siebie nawzajem źródłem sensu ${ }^{30}$. Pragnienie stworzenia związku i jednocześnie obawa przed utratą niezależności to nieustające poszukiwanie równowagi pomiędzy byciem z sobą a byciem razem. Według Giddensa, gdy partnerom nie powiedzie się plan znalezienia równowagi pomiędzy wspólnotą uczuć i doświadczeń a autonomią i będą zbyt blisko, relacja może prowadzić do współuzależnienia. Bardziej prawdopodobne wydaje się jednak, że partnerzy w relacji będą od siebie zbyt daleko ${ }^{31}$. Rozdarcie między „ja” i „my”, niemożność emocjonalnego zaangażowania prowadzą do upłynnienia więzi i zaburzają „moralność we dwoje”. Partnerzy są - powołam się tutaj na Baumana - „razem, ale jednak osobno", a równość i współdecydowanie stają się fikcją, jeśli potrzeby indywidualne wyznaczają horyzont podejmowania decyzji, wówczas bowiem decyzją jednej osoby związek może zostać zakończony $^{32}$.

Zarówno entuzjastycznie nastawiony do omawianych zmian Giddens, jak i oceniający ich istotę krytycznie Bauman zakładają, że ewentualne "problemy” z intymnością zostaną rozwiązane jeśli nie w toku indywidualnej pracy i dzięki refleksyjności, to przy wsparciu terapeutycznym, do którego współcześnie odwołujemy się nad wyraz często i które jest jednym z nośników zmiany emocjonalnej.

\section{Przyczyny ochładzania emocjonalności}

Zasadnicze źródło przemian w intymności nie tkwi - jak się wydaje - w dewaluacji samej relacji, ale ma raczej charakter strukturalny i kulturowy ${ }^{33}$. Całkowity rozpad tradycyjnych struktur społecznych, radykalne oderwanie jednostki od wspólnoty i jej miejsca, a "przywiązanie" do zmiennego i wymagającego zaangażowania rynku pracy i możliwej dzięki niemu konsumpcji doprowadziły do zmiany modelu życia - zniszczyły wspólnotowość i poczucie przynależności. „Świat życia" zaczął być kolonizowany przez konsumpcję, pracę, a relacje międzyludzkie stały się niejasne i niepewne. Jeśli weźmiemy pod uwagę silny wpływ czynników zewnętrznych (kulturowych, rynkowych) na relacje intymne, będziemy mogli podważyć Giddensowską wizję samostwarzającego się w związkach suwerennego „ja”, gdyż to „ja”, tożsamość, podmiot, partner w związku stworzony jest raczej przez

\footnotetext{
${ }^{30}$ U. Beck, E. Beck-Gernsheim: The Normal Chaos of Love..., s. 176.

${ }^{31}$ Ibidem, s. 195.

32 Z. Bauman: Razem, osobno..., s. 25.

${ }^{33}$ U. Beck, E. Beck-Gernsheim: The Normal Chaos of Love..., s. 6-7.
} 
mass media, konsumpcjonizm, terapeutów i psychologów i niezwykle silnie ingerujący w życie prywatne rynek pracy ${ }^{34}$.

Bauman, Illouz i Hochshild doszukują się źródeł ochładzania intymności w rozwoju społeczeństwa konsumpcyjnego i przekonują, iż logika konsumpcyjna zmienia wszystkie sfery życia człowieka. Bauman we wstępie do książki Razem, osobno tak ujmuje związek między ponowoczesną racjonalnością konsumencką a relatywizacją więzi międzyludzkich: „W każdym rodzaju trwałego zobowiązania rozum »płynnie-nowoczesny« wietrzy groźbę opresji; każde nieprzelotne zaangażowanie to dla niego groźba popadnięcia w obezwładniającą zależność. Rozum ten sprzeciwia się wszelkim więzom i więziom, przestrzennym oraz czasowym. Nie ma dla nich miejsca ani zastosowania, dla których »płynnie-nowoczesna« racjonalność konsumencka umiałaby znaleźć uzasadnienie"35.

Nie sposób dyskutować z tezą, iż emocje zawsze były, są i prawdopodobnie będą w centrum sieci władzy wytarzanych przez różnorodne systemy społeczno-kulturowe (na przykład religijne, ideologiczne, polityczne). Współcześnie podobnie działa także rynek pracy ${ }^{36}$. Trudno się nie zgodzić z socjologami, między innymi Eve Illouz, Arlie Russell Hochschild czy wcześniej cytowanym klasykiem - Baumanem, że kapitalizm wywarł najsilniejszy wpływ na nasze życie emocjonalne, wydarł je ze sfery osobistej i przyczynił się do jego utowarowienia, co oznacza, że emocje przestały być tylko prywatne, tylko domeną kobiet i dzieci, ewentualnie artystów, a stały się zasobem pracownika i przedmiotem rozrastającego się rynku produktów i usług. Uczucia zostały posłużę się retoryką Illouz i Hochschild - skomercjalizowane, czyli nauczyliśmy się korzystać z nich jako zasobów do celów konsumpcyjnych i zawodowych: „W kulturze kapitalizmu emocjonalne uczucia stały się bytami, które się ocenia, kontroluje, kwantyfikuje, przekształca w towar, o które można się targować i o których się dyskutuje. [...] Kapitalizm emocjonalny przepełnił transakcje ekonomiczne - faktycznie to większość stosunków społecznych - bezprecedensową troską kulturową o językowe zarządzanie emocjami, postawił je w centrum strategii dialogu, uznania, intymności i autoemancypacji"37. Przyczyn i jednocześnie przejawów komercjalizacji emocji można doszukiwać się w rytualizacji życia poza domem (praca, instytucje, przestrzeń społeczno-kulturowa), która skutkuje w większości dramatycznymi przeobrażeniami rodziny i relacji międzyludzkich.

\footnotetext{
${ }^{34}$ Z. Bauman: Ponowoczesne wzory osobowe..., s. 435-436.

${ }^{35}$ Z. Bauman: Razem, osobno..., s. 140.

${ }^{36}$ E. Illouz: Uczucia $w$ dobie kapitalizmu...

${ }^{37}$ Ibidem, s. 157.
} 
Illouz, podobnie jak Giddens i Bauman, w rosnącym osamotnieniu jednostki, w jej rozdarciu pomiędzy sferą prywatną (rodziną, przyjaciółmi) i sferą publiczną (pracą, relacjami społecznymi) lokuje źródło rozwoju dyskursów terapeutycznych, które są częścią tak zwanej kultury eksperckiej ${ }^{38}$. Bauman w praktykach eksperckich dostrzega przyczyny racjonalizacji i chłodzenia relacji międzyludzkich: „Ekspert wyjaśni ci, że związek z drugim człowiekiem jest inwestycją jak każda inna: angażujesz w niego czas, pieniądze, wysiłek, które mógłbyś obrócić na inne cele. Nie robisz tego jednak, bo masz nadzieję, że postępujesz słusznie”" ${ }^{39}$. Inaczej rolę ekspertów ocenia Giddens: „Wiedza ekspercka w sytuacji nowoczesnej staje się częścią zażyłości: instytucje nowoczesne nie wszczepiają się tak po prostu w »świat przeżywany«, którego pozostałości niewiele różnią się od tego, jakie były zawsze"40, i dlatego prawdopodobnie odrzuca tezę o kolonizowaniu świata przeżywanego przez działania eksperckie. Zarówno indywidualizm w podejściu terapeutycznym, jak i odwołanie do refleksyjności osoby powodują jednak, że dyskursy terapeutyczne pogłębiają i utrwalają indywidualizm aksjologiczny. W dyskursie terapeutycznym za pomocą kategorii autonomii i poszerzania pola wolności zachęca się do racjonalizowania emocji - sugeruje się samoobserwację, opisywanie przeżyć neutralnym językiem i zachowywanie dystansu, unikanie silnych i bliskich relacji, które mogą ograniczać niezależnośćc1. Emocje, ze swej istoty naturalne i osobiste, stają się częścią emocjonalnego wizerunku (emotional makeup), są poddawane racjonalizacji w procesie pracy emocjonalnej (emotional work), która w pisuje się w szersze zjawisko pracy nad tożsamością ${ }^{42}$. Emocje nie mogą oprzeć się procesom kolonizowania zasobów kulturowych, gdyż są ontycznie związane z konstruowaniem tożsamości, są źródłem świata życia i są przez niego regulowane. Właśnie w procesie kolonizowania zasobów kulturowych dochodzi do chłodzenia emocjonalności - emocje zostają oddzielone od utrwalonej kulturowo funkcji wyrażania osobistych odczuć. Za Jürgenem Habermasem można powtórzyć, że następuje instrumentalizacja i jurydyzacja reguł wyrażania i ekspresji uczuć ${ }^{43}$. Ten „stan emocjonalności”, zdaniem Illouz, to

${ }^{38}$ Ibidem.

39 Z. Bauman: Razem, osobno..., s. 28.

40 A. Giddens: Konsekwencje nowoczesności. Przekł. E. Klekot. Kraków 2008, s. 101.

${ }^{41}$ E. Illouz: Uczucia $w$ dobie kapitalizmu..., s. 26.

42 Z. Bauman, T. Leoncini: Płynne pokolenie. Z włoskiego przeł. S. Żuchowski. Warszawa 2018; A.R. Hochschild: Commercialization of Intimate Life...

${ }^{43}$ J. Habermas: Teoria działania komunikacyjnego. T. 2: Przyczynek do krytyki rozumu funkcjonalnego. Przeł. A.M. Kaniowski. Przekł. przejrzał M.J. Siemek. Warszawa 2002, s. 220. 
kapitalizm emocjonalny, który przepełnił większość stosunków społecznych bezprecedensową troską o językowe zarządzanie emocjami, postawił je w centrum strategii dialogu, uznania i autoemancypacji ${ }^{44}$.

$\mathrm{Na}$ tle zasygnalizowanych związków pomiędzy rozwojem dyskursów eksperckich i chłodzeniem (racjonalizowaniem) emocjonalności ujawnia się znaczenie postępującej indywidualizacji, która przejawia się radykalizacją wolności i skrajnie indywidualistycznymi wzorami kultury - nadmierna koncentracja na „ja” ujawnia się także w skryptach emocjonalnych ${ }^{45}$. W kulturze indywidualistycznej ${ }^{46}$ wartością jest, poza autonomią i samoświadomością, niezależność emocjonalna, którą osiąga się w odniesieniu do własnych myśli i uczuć, a nie poprzez odwołanie do myśli, uczuć i działań innych. Inaczej niż w kulturze kolektywnej, relacje nie opierają się tutaj na więzi emocjonalnej i wzajemności, a na wymianie (rywalizacja, współpraca); wymiana wprawdzie nie wyklucza silnych związków emocjonalnych, relacje są jednak częściej jednym ze sposobów autoekspresji: „Inni albo sytuacje społeczne są ważne, ale przede wszystkim jako standard oceny, źródło samopotwierdzenia istoty swojej tożsamości" ${ }^{47}$.

Wszechobecny nacisk na samorealizację i sukces jednostki, zanikanie wyraźnej granicy pomiędzy sferą prywatną i publiczną powodują przesuwanie się zaangażowania z życia rodzinnego, które dla wielu przestaje być miejscem spełnienia, na pracę zawodową, życie towarzyskie i realizację własnych zainteresowań. Praca zaczyna nabierać znaczenia pozaekonomicznego i coraz częściej wiąże się ze statusem społecznym, wymaga oddania i zaangażowania emocjonalnego. Pracodawcy wiążą pracowników z firmą na różne sposoby (pakiety socjalne, wyjazdy integracyjne), wydłużają czas pracy, tworzą poczucie kompetencji i osiągnięć (nagrody, dyplomy, tytuły, awanse). Wszystko to sprawia, że kiedyś wyraźny podział pomiędzy kulturą domu i pracy zaciera się: sfera publiczna (praca, media) rytualizuje się, a dom i intymność ulegają derytualizacji ${ }^{48}$.

Konieczność godzenia obowiązków domowych, zawodowych i społecznych przy rosnącej presji osiągania sukcesu oraz konieczności

\footnotetext{
${ }^{44}$ E. Illouz: Uczucia $w$ dobie kapitalizmu..., s. 157.

45 Ibidem.

${ }^{46}$ Badania antropologiczne potwierdzają, że w czystej postaci żadna kultura nie jest ani indywidualistyczna, ani kolektywna, to przeważające syndromy decydują o specyfice danej społeczności. Podaję za: H.R. Markus, S. Kitayama: Culture and the Self: Implications for Cognition, Emotion, and Motivation. „Psychological Review" 1991, vol. 98, no. 2, s. 224-253.

${ }^{47}$ Ibidem, s. 226, tłum. - I.P.

${ }^{48}$ A.R. Hochschild: Zarządzanie emocjami..., s. 208.
} 
potwierdzania swojego statusu społecznego zmusza do ekstremalnego zarządzania emocjami. Jedną ze strategii przetrwania w niestabilnej kulturze i ochrony przed przeciążeniem emocjonalnym jest - coraz częściej obserwowany - emocjonalny ascetyzm (emotional asceticism); partnerzy (rodzice) dystansują się wobec pełnienia ról domowych po to, by obniżyć emocjonalne koszty przebywania poza domem ${ }^{49}$. Na naszych oczach dokonuje się specyficzna redukcja emocjonalna: „rodziny dochodzą do wniosku, że dom, małżeństwo, a nawet dzieci »potrzebują mniej « niż dotychczas sądzono"50. Między innymi outsourcing obowiązków prywatnych i domowych, czyli zlecanie zadań związanych z życiem rodzinnym, zwłaszcza tych wymagających zaangażowania, jak opieka nad dziećmi i starszymi rodzicami, umożliwia redukcję emocjonalnego zaangażowania w domu. Taki outsourcing wtórnie zmienia rodzinę, nie tylko wyręcza jej członków z codziennych obowiązków, lecz także zmienia jej rytuały, przyzwyczajenia i relacje emocjonalne, zażyłość, przywiązanie i oddanie przekształca w relację, która nosi znamiona transakcji ${ }^{51}$. Można powiedzieć, że outsourcing oznacza urynkowienie zacisza domowego, co pociąga za sobą rosnące zapotrzebowanie na zawody usługowe, także związane z opieką. Hochschild obrazowo nazywa je „rynkowym przedłużeniem” roli matki, ojca, żony czy męża ${ }^{52}$. Właśnie to, że coraz częściej życiem prywatnym zajmują się osoby obce, eksperci i specjaliści, przyczynia się do postępującej transmutacji uczuć - chłodzenia emocjonalności w sferze domowej (prywatnej) i wzrostu zaangażowania emocjonalnego poza domem.

W poczynionych rozważaniach moją intencją było wskazanie związku między rosnącą emancypacją relacji i kryzysem więzi międzyludzkich a przemianami w kulturze emocjonalnej. Zaproponowałam odczytanie kryzysu przez pryzmat koncepcji Anthony'ego Giddensa, Zygmunta Baumana, Arlie Russell Hochschild i Eve Illouz. Badacze ci za pomocą właściwych sobie aparatów pojęciowych i perspektyw badawczych opisują ochładzanie relacji międzyludzkich i powołując się na paradygmat

\footnotetext{
${ }^{49}$ A.R. Hochschild: Commercialization of Intimate Life..., s. 283.

${ }^{50}$ Ibidem.

${ }^{51}$ K. Sandholtz et al.: Beyond Juggling, Rebalancing Your Busy Life. W: Born to Buy: the Commercialized Child and the New Consumer Culture. Ed. J.B. Schor. New York 2004, s. 56.

52 A.R. Hochschild: „Rent a Mom” and Other Services: Markets, Meanings and Emotions. „International Journal of Work Organisation and Emotion” 2005, vol. 1 , no. 1 .
} 
elastyczności i refleksyjności, tłumaczą przemiany form zawieranych związków oraz motywacje do ich tworzenia. Tendencje te wpisują się w zindywidualizowany model relacji międzyludzkich, oparty na uczuciu, a nie zobowiązaniach formalnych. Przyczyn ochładzania emocjonalności można - jak piszą badacze - upatrywać przede wszystkim w rozwoju kapitalizmu (wymogi rynku pracy) i psychologizacji życia, zwłaszcza w dominacji dyskursu terapeutycznego i eksperckiego. Wydaje się, że obserwowane przemiany w więziach społecznych i związane z nimi ochładzanie uczuć w sferze prywatnej stanowią szczególny przypadek zaburzenia reprodukcji symbolicznej Lebensweltu. Derytualizacja świata życia następuje pod wpływem medialnych, podporządkowanych logice konsumpcyjnej wzorów domu, rodziny i bliskości oraz poppsychologii ${ }^{53}$, która zachęca do zarządzania emocjonalnością i intymnością.

Współczesne przemiany więzi międzyludzkich naznaczone są napięciami i mimo iż ocena tych zmian wydaje się jednoznaczna - mamy do czynienia z kryzysem relacji - to w pewnym sensie dokonał się relatywnie znaczący wzrost wolności i równości w związkach. Jednakże ponowoczesna emancypacja podmiotu jako refleksyjne programowanie własnego rozwoju oraz emancypacja związków jako negocjacja wartości okazują się pozorne, gdyż towarzyszy im uzależnienie jednostki od nieustającego samopotwierdzania własnej niezależności i jednocześnie kulturowo wzmacniany przymus wchodzenia w relacje. Zdekonstruowane przez media wzory intymności, domu i rodziny wracają do sfery prywatnej i komercjalizują świat życia, który przestaje być światem uczuć - nawet jeśli zmiennych i negatywnych w doznaniach, to prawdziwych - a staje się światem sztucznie indukowanych emocji, dosłownie tworzonych przez technologię (media), a w przenośni - skolonizowanych przez technologię. Zapośredniczenie emocjonalności przez komunikację masową, zdziczenie emocjonalności w tekstach kultury popularnej i niejednokrotnie w sferze publicznej nie pozostawia wątpliwości - jesteśmy świadkami niespotykanej do tej pory w kulturze zmiany emocjonalnej. Jeszcze w latach dziewięćdziesiątych XX wieku wydawało się, że deklarowany zwrot antropologiczny doprowadzi do przewartościowań, dzięki którym emocje zyskają należny im status wartości i mądrości, kierunek zmian okazał się jednak bardzo niepokojący, gdyż na naszych oczach podważane są obwarowania aksjonormatywne i podstawowe reguły życia społecznego. Skutki tychże zmian obserwujemy na co dzień w rosnącym niepokoju społecznym, zagubie-

${ }^{53}$ Korzystam z pojęcia wprowadzonego przez Lutz, która postawiła tezę, iż rozwój dyskursów eksperckich następuje pod wpływem popularyzowania wiedzy psychologicznej i powszechnej dostępności do niej. 
niu egzystencjalnym i niesamodzielności emocjonalnej dorosłych oraz osamotnieniu dzieci i młodzieży.

\section{Bibliografia}

Adamczyk M.: Wprowadzenie do teorii kapitału społecznego. Lublin 2013.

Bauman Z.: Ponowoczesne wzory osobowe. „Studia Socjologiczne” 2001, nr 1 (200), s. 7-31.

Bauman Z.: Razem, osobno. Przeł. T. Kunz. Kraków 2003.

Bauman Z., Leoncini T.: Płynne pokolenie. Z włoskiego przeł. S. Żuchowski. Warszawa 2018.

Beck U., Beck-Gernsheim E.: The Normal Chaos of Love. Cambridge 1995.

Cassirer E.: Esej o człowieku. Wstęp do filozofii kultury. Przeł. A. Staniewska. Przedmową poprzedził B. Suchodolski. Wyd. 2. Warszawa 1977.

Giddens A.: Konsekwencje nowoczesności. Przekł. E. Klekot. Kraków 2008.

Giddens A.: Nowoczesność $i$ tożsamość. "Ja" i społeczeństwo w epoce późnej nowoczesności. Tłum. A. Szulżycka. Wyd. 2. Warszawa 2010.

Giddens A.: Przemiany intymności: seksualność, miłość i erotyzm we wspótczesnych społeczeństwach. Przeł. A. Szulżycka. Warszawa 2006.

Giddens A.: Socjologia. Współpr. Ph.W. Sutton. Tłum. O. Siara, A. Szulżycka, P. Tomanek. Warszawa 2012.

Giza-Poleszczuk A.: Rodzina a system społeczny. Reprodukcja i kooperacja $w$ perspektywie interdyscyplinarnej. Warszawa 2005.

Grochalska M.: Kobiety w związkach jako ofiary dyskursu „szczęśliwej rodziny". W: Zagadnienia małżństwa i rodzin $w$ perspektywie feministyczno-genderowej. Red. K. Slany. Kraków 2013, s. 143-156.

Habermas J.: Teoria działania komunikacyjnego. T. 2: Przyczynek do krytyki rozumu funkcjonalnego. Przeł. A.M. Kaniowski. Przekł. przejrzał M.J. Siemek. Warszawa 2002.

Hochschild A.R.: The Commercialization of Intimate Life: Notes from Home and Work. Berkeley-Los Angeles 2003.

Hochschild A.R.: „Rent a Mom” and Other Services: Markets, Meanings and Emotions. „International Journal of Work Organisation and Emotion” 2005, vol. 1, no. 1. https://doi.org/10.1504/IJWOE.2005.007328.

Hochschild A.R.: Zarządzanie emocjami. Komercjalizacja ludzkich uczuć. Tłum. J. Konieczny. Warszawa 2009.

Illouz E.: Uczucia $w$ dobie kapitalizmu. Przeł. Z. Simbierowicz. Z oryginałem porównał J. Niżnik. Zredagowała, indeks osób i postaci wraz z notą biograficzną przygotowała E. Nowakowska-Sołtan. Warszawa 2010.

Jamieson L.: Intimacy: Personal Relationships in Modern Societies. Cambridge-Malden 1998. 
Markus H.R., Kitayama S.: Culture and the Self: Implications for Cognition, Emotion, and Motivation. „Psychological Review” 1991, vol. 98, no. 2, s. 224-253.

Marody M.: Jednostka po nowoczesności: perspektywa socjologiczna. Wyd. 2, dodruk. Warszawa 2016.

McNair B.: Porno? Chic!: How Pornography Changed the World and Made It a Better Place. Abingdon-New York 2012.

Sandholtz K. et al.: Beyond Juggling, Rebalancing Your Busy Life. W: Born to Buy: the Commercialized Child and the New Consumer Culture. Ed. J.B. Schor. New York 2004.

Weeks J.: The World We Have Won: The Remaking of Erotic and Intimate Life Since 1945. London-New York 2007. 